\title{
Outbreak of KPC-2 producing Serratia marcescens MDR in a tertiary hospital in the
}

\section{Midwest region, Brazil}

Surto de Serratia marcescens MDR produtora de KPC-2 em hospital terciário da região Centro-

Oeste, Brasil

Brote de Serratia marcescens MDR productora de KPC-2 en hospital terciario de la región Centro

Oeste, Brasil

Received: 07/09/2021 | Reviewed: 07/19/2021 | Accept: 07/22/2021 | Published: 07/30/2021

\author{
Thalita Priscila Peres Seabra da Cruz \\ ORCID: https://orcid.org/0000-0002-0167-6710 \\ Universidade Federal de Mato Grosso, Brazil \\ E-mail: thaly.prii@hotmail.com \\ Francisco Kennedy Scofoni Faleiros de Azevedo \\ ORCID: https://orcid.org/0000-0003-0477-9501 \\ Universidade Federal de Mato Grosso, Brazil \\ E-mail: fksfazevedo@gmail.com \\ Marco Andrey Pepato \\ ORCID: https://orcid.org/0000-0002-7896-6329 \\ Universidade Federal de Mato Grosso, Brazil \\ E-mail: mcoandrey@gmail.com \\ Alessandra Tammy Hayakawa Ito de Sousa \\ ORCID: https://orcid.org/0000-0002-7524-2173 \\ Universidade Federal de Mato Grosso, Brazil \\ E-mailtammyhito@gmail.com \\ Paula Sossai Rizzo \\ ORCID: https://orcid.org/0000-0003-0934-5139 \\ Universidade Federal de Mato Grosso, Brazil \\ E-mail: paulasossai@yahoo.com.br \\ Francisco José Dutra Souto \\ ORCID: https://orcid.org/0000-0002-2529-4119 \\ Universidade Federal de Mato Grosso, Brazil \\ E-mail: fsouto@gmail.com \\ Luciano Nakazato \\ ORCID: https://orcid.org/0000-0002-1244-0690 \\ Universidade Federal de Mato Grosso, Brazil \\ E-mail: lucnaka@gmail.com \\ Valéria Dutra \\ ORCID: https://orcid.org/0000-0002-6630-2293 \\ Universidade Federal de Mato Grosso, Brazil \\ E-mail: valeriadutra.dutra@gmail.com
}

\begin{abstract}
About 700,000 deaths per year worldwide are caused of Healthcare-related infections (HAI). Result in significant patient morbidity and mortality, being is ranked the fourth leading cause of death in Brazil. Usually, HAI are caused by multidrug-resistance microorganisms (MDR), as well as Serratia marcescens, that is associated with healthcarerelated infections causing high patient mortality and morbidity. This paper describes an outbreak of S. marcescens MDR carrier gene blaKPC-2 in a university hospital, with the need to broadly combat horizontal transmission of this bacterium between patients, as well as the need to optimize treatment with other antimicrobial classes due to resistance of this microorganism to polymyxins. Ten isolates were analyzed for the presence of carbapenemic resistance gene blaKPC-2. This gene was detected in all isolates, with a corresponding high patient mortality rate, highlighting the importance of its molecular detection, which corroborates the resistance of $S$. marcescens to carbapenem antibiotics. The detection of this gene is necessary due to the importance to broadly combat horizontal transmission of this bacterium between patients, as well as the need to optimize treatment with other antimicrobial agents due to its resistance to polymyxins.
\end{abstract}

Keywords: S. marcescens; Health-related infection; Outbreak; BlaKPC. 
Research, Society and Development, v. 10, n. 9, e45110918078, 2021

(CC BY 4.0) | ISSN 2525-3409 | DOI: http://dx.doi.org/10.33448/rsd-v10i9.18078

\begin{abstract}
Resumo
Cerca de 700.000 mortes por ano em todo o mundo são causadas por infecções relacionadas à saúde (IRA). Resultam em significativa morbimortalidade de pacientes, sendo classificada como a quarta maior causa de óbito no Brasil. Geralmente, as IRAS são causadas por microrganismos multirresistentes a antimicrobianos (MDR), assim como Serratia marcescens, que está associada a infecções relacionadas à saúde, causando alta mortalidade e morbidade dos pacientes. Este trabalho descreve um surto causado por $S$. marcescens MDR portadora do gene blaKPC-2 em um hospital universitário, com a necessidade de combater amplamente a transmissão horizontal dessa bactéria entre os pacientes, bem como a necessidade de otimizar o tratamento com outras classes de antimicrobianos devido à resistência deste microrganismo às polimixinas. Dez isolados foram analisados quanto à presença do gene de resistência carbapenêmico blaKPC-2. Este gene foi detectado em todos os isolados, com correspondente taxa de mortalidade alta dos pacientes, evidenciando a importância de sua detecção molecular, que corrobora com a resistência de $S$. marcescens aos antibióticos carbapenêmicos. A detecção deste gene faz-se necessária devido à importância de combater amplamente a transmissão horizontal dessa bactéria entre os pacientes, bem como a necessidade de otimizar o tratamento com outros antimicrobianos devido à sua resistência às polimixinas.
\end{abstract}

Palavras-chave: S. marcescens; Infecção relacionada à saúde; Surto; BlaKPC.

\title{
Resumen
}

Aproximadamente 700.000 muertes por año en todo el mundo son causadas por infecciones asociadas a atención de salud (IAAS) las cuales resultan en significativa morbimortalidad de pacientes. Como consecuencia estas infecciones son clasificadas como la cuarta mayor causa de muertes en Brasil. Generalmente, las IAAS, son causadas por microorganismos multirresistentes a los antimicrobianos (MDR, del inglés multidrug-resistance), así como el Serratia marcescens, que está asociado a infecciones relacionadas a la atención intrahospitalar. Este trabajo describe un brote causado por $S$. marcescens multirresistente portadora del gen blaKPC-2 en un hospital universitário. Delante de la necesidad de combatir eficazmente la transmisión horizontal de esta bactéria entre los pacientes y también la necesidad de optimizar el tratamiento con otras clases de antimicrobianos debido a la resistencia de este microrganismo a las polimixinas, fueron analizadas diez muestras en relación a la presencia del gen de resistencia carbapenêmico blaKPC-2. Este gen fué detectado en todas las muestras con tasa de mortalidad alta, evidenciando la importancia de su detección molecular, además de corroborarse la resistência de S. marcescens a los antibióticos carbapenêmicos. Este estúdio se hace necesário debido a la importancia de combatir la transmisión horizontal de la bactéria entre los pacientes, como tambien es importante mejorar el tratamento con otros antimicrobianos delante de la resistencia a las polimixinas.

Palabras clave: $S$. marcescens; Infección asociadas a atención de salud; Brote; BlaKPC.

\section{Introduction}

Healthcare-related infections (HAI) are considered a serious medical and social problem, resulting in significant patient morbidity and mortality. They are caused by multidrug-resistance microorganisms (MDR), causing about 700,000 deaths per year worldwide, and may reach ten million by the year 2050 (IACG, 2019). In developing countries, HAI may be up to 20 times higher than in developed countries (Allegranzi et al., 2011). In Brazil, HAI occupy the fourth leading cause of death (Silva \& Lincopan, 2012).

Serratia marcescens (S. marcescens) can be isolated in the skin, tracheal secretion, urine and feces of critically ill patients, also found in contaminated invasive medical devices, intravenous and topical solutions, liquid soaps and intensive care unit (ICU) air conditioning, favoring the emergence of colonization of patients and hospital outbreaks (Polilli, et al., 2011). According to Quezada-Aguiluz et al. (2020), this opportunistic pathogen of interest to public health has been neglected, even with high rates of antimicrobial resistance.

S. marcescens stands out for its intrinsic and acquired resistance to a variety of antibiotic classes, including $\beta$-lactams, aminoglycosides, quinolones, macrolides and polypeptides (Sandner-Miranda et al., 2016). Thus, the drugs that present greater efficacy in the treatment of infections caused by multiresistant Gram-negative bacteria are the carbapenems however, there has been an increase in resistance rates to these antibiotics in recent years in this group (Cristina et al., 2019), which can be explained by the fact that carbapenemase (KPC) genes are often inserted through conjugative plasmids, which makes $S$. 
marcescens resistant to carbapenems, causing great concern for the reduction of therapeutic options in AIH (Silva et al., 2015).

This study describes the outbreak of $S$. marcescens MDR carrier gene blaKPC-2 in a university hospital, with the need to broadly combat horizontal transmission of this bacterium between patients, as well as the need to optimize treatment with other antimicrobial classes due to resistance of this microorganism to polymyxins.

\section{Methodology}

A total of ten isolates were obtained from ten ICU patients, medical and surgical wards of a tertiary public university hospital in Cuiabá, Mato Grosso, Brazil's Midwestern Region, which has 118 beds. Samples were collected from patients as hospital routine between September and December 2018 (Table 1). The identification of S. marcescens of the samples was performed in the Vitek2 system (BioMérieux, Marcy l'Etoile, França) and confirmed by the MALDI-TOF technique (Matrix Associated Laser Desorption-Ionization - Time of Flight).

Table 1: Patient clinical data: Age, sex and underlying disease of the patients included in the study; Sample type; Patient's situation and place of admission; Length of stay; Outcome of the patient.

\begin{tabular}{|c|c|c|c|c|}
\hline $\begin{array}{l}\text { Patient's age (years), sex, } \\
\text { underlying disease }\end{array}$ & Type of sample & $\begin{array}{c}\text { Patient situation and location } \\
\text { hospital admission }\end{array}$ & $\begin{array}{c}\text { Time to } \\
\text { hospitalization (days) }\end{array}$ & Outcome \\
\hline $\begin{array}{c}74, \mathrm{M}, \\
\text { neurocryptococcosis }\end{array}$ & $\begin{array}{l}\text { Aspirated } \\
\text { tracheal }\end{array}$ & MVAP $*$, adult ICU** & 84 & Death \\
\hline $\begin{array}{c}84, \mathrm{~F} \text {, acute myocardial } \\
\text { infarction }\end{array}$ & $\begin{array}{l}\text { Aspirated } \\
\text { tracheal }\end{array}$ & MVAP $*$, medical clinic ward & 53 & Death \\
\hline $\begin{array}{c}60, \mathrm{M}, \text { adenocarcinoma of } \\
\text { prostate }\end{array}$ & Tip of catheter & Colonization, ambulatory & Not hospitalized & Cure \\
\hline 63, F, leprosy & Rectal swab & Sepse, medical clinic ward & 27 & Cure \\
\hline $\begin{array}{c}57, \mathrm{M}, \\
\text { pulmonary aspergillosis }\end{array}$ & Pleural liquid & Pneumonia, medical clinic Ward & 36 & Cure \\
\hline $\begin{array}{l}71, \mathrm{M}, \mathrm{HIV} \text { and } \\
\text { pneumocystosis }\end{array}$ & $\begin{array}{l}\text { Aspirated } \\
\text { tracheal }\end{array}$ & Pneumonia, ICU** & 61 & Death \\
\hline $\begin{array}{c}40, \mathrm{~F}, \\
\text { leprosy and cholecystitis }\end{array}$ & Rectal swab & $\begin{array}{c}\text { Colonization, ICU** and Clinic } \\
\text { Surgical ward }\end{array}$ & 30 & Cure \\
\hline $\begin{array}{l}\text { 56, M, diaphragmatic hernia } \\
\text { and emergency laparotomy }\end{array}$ & $\begin{array}{l}\text { Abdominal } \\
\text { secretion }\end{array}$ & $\begin{array}{l}\text { Intrabdominal infection, clinic } \\
\text { Surgical ward and ICU }\end{array}$ & 49 & Cure \\
\hline $\begin{array}{l}\text { 18, M, hemolytic anemia and } \\
\text { disseminated histoplasmosis }\end{array}$ & $\begin{array}{l}\text { Synovial } \\
\text { Liquid }\end{array}$ & $\begin{array}{l}\text { Septic elbow arthritis, medical } \\
\text { clinic ward }\end{array}$ & 85 & Cure \\
\hline $\begin{array}{c}65, \mathrm{M} \text {, pemphigus foliaceus and } \\
\text { dialytic renal failure }\end{array}$ & Blood & Bloodstream infection, ICU & 33 & Death \\
\hline
\end{tabular}

* MVAP: mechanical ventilation-associated pneumonia

** ICU: intensive care unit (ICU)

Source: Authors.

Susceptibility profiles were based on Minimum Inhibitory Concentration (MIC) by Bact / Alert 3D and Vitek2 (BioMérieux, Marcy l'Etoile, France), where seven classes of antimicrobials were tested. Isolates were classified as sensitive, 
Research, Society and Development, v. 10, n. 9, e45110918078, 2021

(CC BY 4.0) | ISSN 2525-3409 | DOI: http://dx.doi.org/10.33448/rsd-v10i9.18078

resistant, or intermediate sensitive according to Clinical \& Laboratory Standarts Institute Guidelines (CLSI, 2017).

Genomic DNA extraction from isolates was performed by the phenol-chloroform method according to Sambrook and Russel (2004). The extracted DNAs were submitted to PCR of the KPC-2 carbapenemase resistance gene. The oligonucleotide sequence used was that described by Yigiti et al. (2001). Subsequently, the PCR product was purified with the GE Healthcare Life Sciences illustra ExoProStar Kit and used in the sequencing reaction along with the BigDye Terminator Ready Reaction Cycle Sequencing (Applied Biosystems) in auto sequencer 3500 Genetic Analyzer (Applied Biosystems).

\section{Results and Discussion}

Of the ten patients, six were male $(60 \%)$ and four female $(40 \%)$. The average age of the patients was $58.8( \pm 18.56)$ years. The clinical data of the patients are described in Table 1, and the patients presented severe intercurrent diseases demonstrating the opportunistic infection character of S. marcescens (Polilli et al., 2011).

In this study, the mortality rate was 40\% (4/10), similar to other reports that varied from 14 to $60 \%$ (Arslan et al., 2010; Milisavljevic et al,. 2004), requiring a larger study relating the search for resistance genes of isolates and mortality, as HAI along with antimicrobial resistance, especially carbapenem resistance, increase patient mortality and morbidity rates, as well as their costs and length of stay (Kaleem et al., 2010).

The isolates showed in vitro resistance to the following antimicrobial classes: penicillins (piperacillin / tazobactam $\mathrm{n}=10,100 \%$ ), cephalosporins (cefepime $\mathrm{n}=10,100 \%$ ), carbapenemics (imipenem $\mathrm{n}=10,100 \%$; meropenem $\mathrm{n}=10,100 \%$; ertapenem $n=10,100 \%$ ), quinolones (ciprofloxacin $n=10,100 \%$ ), polymyxins (polymyxin $B \mathrm{n}=10,100 \%$ ). The emergence of antimicrobial resistance in $S$. marcescens is preceded by widespread use of the antibiotic in hospital settings such as betalactams, aminoglycosides, fluoroquinolones (Jones, 1998; Hejazi \& Falkiner, 1997) and colistin (Silva et al., 2015). In relation to aminoglycosides, $100 \%$ were resistant to amikacin and $10 \%$ to gentamicin. This difference may be associated with the occurrence of the gene pREM-1 [aac (6') - 30] conferring reduced susceptibility to amikacin and not gentamicin (Mendes et al. 2004).

The best result was glycylcyclines (tigecycline) with only $20 \%$ resistance, however the occurrence of SdeXY-HasF efflux pumps in $S$. marcescens decreases their activity as well as gallbladder excretion that may make treatment difficult. of urinary infections (Hornsey, 2010; Peleg \& Hooper, 2010).

Only one patient was resistant to all classes of antimicrobials. In addition to this, two patients had intermediate sensitivity to tigecycline and one patient with intermediate sensitivity to gentamicin, gentamicin and tigecycline being the only antimicrobials to which isolates were susceptible. All patients who died had susceptibility to gentamicin and tigecycline, except one patient who had intermediate sensitivity to gentamicin (Table 2). 
Table 2: Classes of antibiotics, antimicrobial used and their respective microbial resistance rates (\%).

carbapenem

blaKPC-2 gene

observed in all

(Figure 1), with meropenem

ertapenem

phenotypes.

are associate

\begin{tabular}{c|c|c}
\hline Antimicrobial Classes & Antibiotic & Resistance \\
\hline Penicillins & Piperacillin + tazobactam & $100 \%(10 / 10)$ \\
\hline Cephalosporins & Cefepime & $100 \%(10 / 10)$ \\
Carbapenemics & Imipenem & $100 \%(10 / 10)$ \\
& Meropenem & $100 \%(10 / 10)$ \\
\hline Quinolones & Ertapenem & $100 \%(10 / 10)$ \\
\hline Polymyxins & Ciprofloxacin & $100 \%(10 / 10)$ \\
\hline Aminoglycosides & Polymyxin B & $100 \%(10 / 10)$ \\
\hline Glycylcyclines & Gentamicin* & $20 \%(2 / 10)^{*}$ \\
\hline
\end{tabular}

*The intermediate sensitivity isolates were considered resistant. Source: Authors. isolates were resistant and detection was isolates imipenem, and resistance This finding with high mortality rate compared to KPC negative isolates (Silva et al. 2015).

The bacteria of the Enterobacteriaceae family that extended-spectrum $\beta$-lactamase producing and resistant to carbapenem antibiotics have been classified by the World Health Organization (WHO) as critical pathogens for which further research is urgently needed (Tacconelli et al., 2018). In Brazil, other genes such as blaIMP-10, blaSME-4 and blaTEM1 have also been described, emphasizing the need for investigation of carbapenemic resistance genes due to the great importance of this antimicrobial class in the treatment of, especially in a healthcare setting where carbapenems are primarily used as a last-line treatment for gram-negative MDR bacterial infections HAI (Cayô et al. 2017; Margate et al. 2015; Silva et al. 2015).

Figure 1: Amplification of the KPC-2 gene fragment (1011bp) in all isolates (1-10); M: marker (Ladder 100bp); CN: negative control; $\mathrm{CP}$ : positive control.

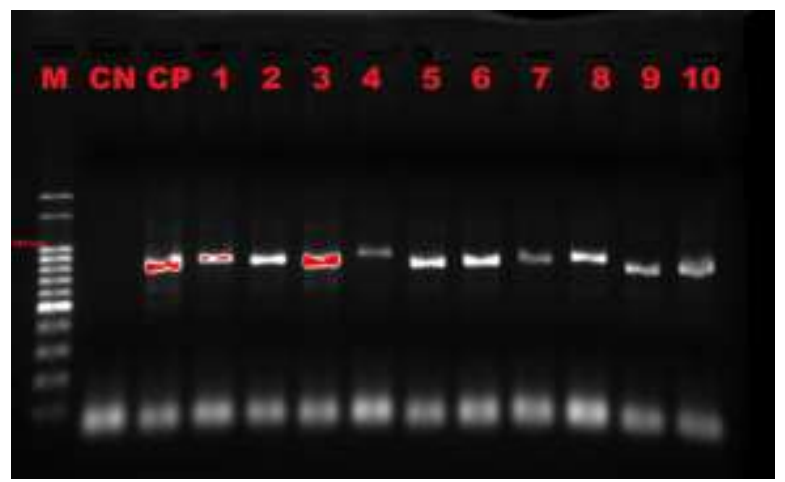

Source: Personal archive.

Due to the intrinsic resistance of S. marcescens to polymyxins (Silva et al. 2015; Denervaud-Tendon et al., 2017), finding the presence of carbapenemases becomes essential for the choice of the most appropriate antibiotics in order to achieve therapeutic success. 
Research, Society and Development, v. 10, n. 9, e45110918078, 2021

(CC BY 4.0) | ISSN 2525-3409 | DOI: http://dx.doi.org/10.33448/rsd-v10i9.18078

\section{Conclusion}

We observed that $S$. marcescens isolates from this study caused high mortality with high resistance profile. Thus, genomic studies should be performed in order to clarify whether such microorganisms are clonal in Cuiabá, alerting to the importance of $S$. marcescens in the Midwest region and possibly in other regions of Brazil. It is concluded that rapid detection methods should be performed in reference health units to verify early detection of resistance genes and to improve antimicrobial treatment, reducing the horizontal transfer of antimicrobial resistance genes.

\section{Approvals and ethical statements}

The research project was approved by the Research Ethics Committee of the Júlio Muller University Hospital, and was registered with the National System of Ethical Evaluation of Human Research Projects (CAAE 17331119.2.0000.5541).

\section{References}

Allegranzi, B., Bagheri Nejad, S., Combescure, C., Graafmans, W., Attar, H., Donaldson, L.,\& Pittet, D. (2011). Burden of endemic health-care-associated infection in developing countries: systematic review and meta-analysis. Lancet, 377 (9761), 228-241. doi 10.1016 / S0140-6736 (10) 61458-4

Arslan, U., Erayman, I., Kirdar, S., Yuksekkaya, S., Cimen, O., Tuncer, I., \& Bozdogan, B. (2010). Serratia marcescens sepsis outbreak in a neonatal intensive care unit. Pediatrics International, 52, 208-212. doi:10.1111/j1442-200X.2009.02934.X

Cayô, R., Leme, R.C., Streling, A.P., Matos, A.P., Nodari, C.S., Chaves, J.R., Brandão, J.L., De Almeida, M.F., Carrareto, V., De Castro Pereira, M.A., De Almeida, J.P., Ferreira, D.C., \& Gales, A.C. (2017). Serratia marcescens harboring SME-4 in Brazil: a silent threat. Diagnostic Microbiology and Infectious Disease, 87, 357-358. doi:10.1016/j.diagmicrobio.2017.01.00

Clinical \& Laboratory Standards Institute (CLSI) (2017). "Performance Standards for Antimicrobial Susceptibility Testing: 27th informational supplement M100.” Wayne, PA: Clinical and Laboratory Standards Institute, pp. 46-48.

Cristina, M.L., Sartini, M., \& Spagnolo, A.M. (2019). Serratia marcescens infections in neonatal intensive care units (NICUs). International Journal of Environmental Research and Public Health, 16, (610), 1-10. doi:10.3390/ijerph16040610

Denervaud-Tendon ,V., Poirel, L., Connolly, L.E., Krause, K.M., \& Nordmann, P. (2017). Plazomicin activity against polymyxin-resistant Enterobacteriaceae, including MCR-1-producing isolates. Journal of Antimicrobial Chemotherapy, 72 (10), 2787-2791. doi:10.1093/jac /dkx239

Interagency Coordination Group on Antimicrobial Resistance (IACG) (2019). No time to wait: securing the future from drug-resistant infections. Report to the Secretary-General of the United Nations. https://www.who.int/docs/default-source/documents/no-time-to-wait-securing-the-future-from-drug-resistantinfections-en.pdf?sfvrsn=5b424d7_6

Hejazi, A., \& Falkiner, F.R. (1997). Serratia marcescens. Journal of Medical Microbiology, 46, 903-912. doi.org/10.1099/00222615-46-11-903

Hornsey, M., Ellington, M.J., Doumith, M., Hudson, S., Livermore, D.M., \& Woodford, N. (2010). Tigecycline resistance in Serratia marcescens associated with up-regulation of the SdeXY-HasF efflux system also active against ciprofloxacin and cefpirome. Journal of Antimicrobial Chemotherapy, 65, 479-482. doi:10.1093/jac/dkp475

Jones, R.N. (1998) Important and emerging beta-lactamase-mediated resistances in hospital-based pathogens: the Amp C enzymes. Diagnostic Microbiology and Infectious Disease, 31, 461-466. doi:10.1016/s0732-8893(98)00029-715

Kaleem. F., Usman, J., Hassan, A., \& Khan, A. (2010). Frequency and susceptibility pattern of metallo-beta-lactamase producers in a hospital in Pakistan. The Journal of Infection in Developing Countries, 4 (12), 810-813. doi: 10.3855 / jidc.1050

Margate, E., Magalhães, V., Fehlberg, L.C.C., Gales, A.C., \& Lopes, A.C.S. (2015). KPC-producing Serratia marcescens in a home-care patient from Recife, Brazil. Revista do Instituto de Medicina Tropical de São Paulo, 57 (4), 359-360. doi: 10.1590/S0036-46652015000400016

Mendes, R.E., Toleman, M.A., Ribeiro, J., Sader, H.S., Jones, R.N., \& Walsh, T.R. (2004). Integron carrying a novel metallo- $\beta$-lactamase gene, blaIMP-16, and a fused form of aminoglycoside-resistant gene aac $\left(6^{\prime}\right)-30 / a a c\left(6^{\prime}\right)-\mathrm{Ib}^{\prime}$ : report from the SENTRY Antimicrobial Surveillance Program. Antimicrobial Agents and Chemotherapy Journal, 48, 4693-4702. doi:10.1128/AAC.48.12.4693-4702.2004

Milisavljevic, V., Wu, F., Larson, E., Rubenstein, D., Ross, B., Drusin, L.M., Della-Latta, P., \& Saiman, L. (2004). Molecular epidemiology of Serratia marcescens outbreaks in two neonatal intensive care units. Infection Control \& Hospital Epidemiology., 25, 719-721. doi 10.1086/502466

Peleg, A.Y., \& Hooper, D.C. (2010). Hospital-acquired infections due to gram-negative bacteria. The New England Journal of Medicine, $362,1804-1813$. doi: 10.1056/ NEJMra0904124

Polilli , E., Parruti, G., Fazii, P., D'Antonio, D., Palmieri, D., D'Incecco, C., Mangifesta, A., Garofalo, G., Del Duca, L., D'Amario, C., Scimia , M, Cortesi, V., \& Fortunato, V. (2011). Rapidly controlled outbreak of Serratia marcescens infection/colonisations in a neonatal intensive care unit, Pescara General Hospital, Pescara, Italy. Euro Surveill 16 (24), 1-3. doi:10.2807/ese.16.24.19892-pt 
Research, Society and Development, v. 10, n. 9, e45110918078, 2021

(CC BY 4.0) | ISSN 2525-3409 | DOI: http://dx.doi.org/10.33448/rsd-v10i9.18078

Quezada-Aguiluz., M., Lincopan, N., Cerdeira, L., Fuga, B., Silva, F., Barrera, B., Cifuentes,M., Bello-Toledo, H., Opazo-Capurro, A., \& González-Rocha, G. (2020). Draft genome sequence of a multidrug-resistant KPC-2 and SRT-2 co-producing Serratia marcescens strain isolated from a hospitalised patient in Chile. Journal of Global Antimicrobial Resistanc, 21, 1-2. doi.org/10.1016/j.jgar.2020.02.004

Sambrook,. J, \& Russel, D.W. (2004). Molecular cloning: a laboratory manual. 3 ed. New York; Cold Spring Harbor Laboratory Press pp 5.65-5.67.

Sandner-Miranda, L., Vinuesa, P., Soberón-Chávez, G., \& Morales-Espinosa, R. (2016). Complete genome sequence of Serratia marcescens SmUNAM836, a nonpigmented multidrug-resistant strain isolated from a Mexican patient with obstructive pulmonar y disease. Genome Announcements, 4 (1), e01417-15. doi: 10.1128/genomeA.01417-15.

Silva, K.C., \& Lincopan, N. (2012) Epidemiology of extended-spectrum beta-lactamases in Brazil: Clinical impact and implications for agribusiness. Jornal Brasileiro de Patologia e Medicina Laboratorial, 48 (2), 91-99. doi:10.1590/S1676-24442012000200004

Silva, K.E., Cayô, R., Carvalhaes, C.G, Sacchi, F.P.C., Rodrigues-Costa, F., Silva, A.C.R., Croda, J., Gales, A.C., \& Simionatto, S. (2015). Coproduction of KPC-2 and IMP-10 in Carbapenem-Resistant Serratia marcescens Isolates from an Outbreak in a Brazilian Teaching Hospital. Journal of Clinical Microbiology, 53 (7), 2324-2328. doi:10.1128/JCM.00727-15.

Tacconelli, E., Carrara, E., Savoldi, A., Harbarth, S., Mendelson, M., Monnet, D.L., Pulcini, C., Kahlmeter, G., Kluytmans, J., Carmeli, Y., Ouellette, M., Outterson, K., Patel, J., Cavaleri, M., Cox, E.M., Houchens, C.R., Grayson, M.L., Hansen, P., Singh, N., Theuretzbacher, U., \& Magrini, N. (2018) Discovery, research, and development of new antibiotics: the WHO priority list of antibiotic-resistant bacteria and tuberculosis. The Lancet Infectious Diseases, 18 (3), 318-327. doi:10.1016/S1473-3099(17)30753-3

Yigiti, H., Queenan, A.M., Anderson, G.J., Domenech-Sanchez, A., Biddle, J.W., \& Steward, C.D. (2001). Novel carbapenem-hydrolyzing $\beta$-lactamase, KPC-1, from a carbapenem-resistant strain of Klebsiella pneumoniae. Antimicrobial agents and chemotherapy, 45 (4), $1151-1161$. doi:10.1128/AAC.45.4.1151-1161.2001 